Brit. F. vener. Dis. (1970) 46, 141

\title{
Recent developments in the treatment of gonorrhoea
}

\author{
R. R. WILLCOX \\ St. Mary's Hospital, London, W.2
}

IT is no longer disputed that increasing failure rates in the treatment of gonorrhoea with penicillin and some other antibiotics are related to the emergence of increasing numbers of less sensitive strains of the gonococcus. The problem has become most serious in Far Eastern countries on a war footing where there are repeated frequent exposures between military and prostitute populations in an 'antibiotic environment' (e.g. Korea, Vietnam); failure rates currently of about 30 per cent. are being experienced after treatment with single injections of 2.4 mega units aqueous procaine penicillin (Holmes, Johnson, Floyd, and Kvale, 1967; WHO, 1969) and in some areas even after doses of 4.8 mega units (WHO, 1969).

Although air travel has facilitated the import of resistant strains into other countries, including those of Europe, the problem of lessened sensitivity of the gonococcus to penicillin has not yet reached critical proportions. Factors which have partially controlled the danger include better-developed clinic networks or other established facilities for treatment and contact-tracing, laws preventing the sale of antibiotics except on a physician's prescription, the ready availability of other more expensive antibiotics for the re-treatment of cases of treatment failure, and a much less concentrated activity of prostitutes. Indeed, it has been shown on a local scale that the situation may be capable of being checked or even reversed with changes in treatment practices (Letchner and Nicol, 1961 ; Morton, 1963; Ödegaard and Gjessing, 1967).
However, once high failure rates occur with doses of aqueous procaine penicillin as high as 2.4 mega units, the limits of single injection therapy will shortly be reached, and it is therefore a matter of continuing urgency that alternative methods be developed.

If 'single-session' therapy with all its epidemiological and administrative advantages is to be retained, the available possibilities are:

(1) To increase the dose of aqueous procaine penicillin in routine cases rather than in selected cases of failure;

(2) To raise and prolong the serum level of penicillin by the simultaneous use of probenecid;

(3) To use other antibiotics alone;

(4) To use penicillin or other antibiotics in simultaneous or consecutive combination.

Recent experiences of the treatment of gonorrhoea in male patients in London are outlined in this paper.

\section{Experience with 1.2 mega units of procaine penicillin in a single injection}

For some years the routine treatment at St. Mary's Hospital for male patients with gonorrhoea has been a single injection of 1.2 mega units aqueous procaine penicillin. The results obtained in sample series in three different years are shown in Table $I$.

In assessing these results, admission or denial of further sexual intercourse has been used to distinguish re-infection from treatment failure, except that all recurrences 3 or more months after treatment have been classed as re-infections. Some authors, for

TABLE I Results with single injections of 1.2 mega units of procaine penicillin

\begin{tabular}{|c|c|c|c|c|c|c|c|c|c|c|}
\hline \multirow{3}{*}{ Year } & \multirow{3}{*}{ No. treated } & \multirow{3}{*}{ No. followed } & \multicolumn{3}{|l|}{ Result } & \multirow{3}{*}{$\begin{array}{l}\text { Percentage } \\
\text { failure of cases } \\
\text { followed }\end{array}$} & \multicolumn{4}{|c|}{ All recurrences } \\
\hline & & & \multirow{2}{*}{$\begin{array}{l}\text { Non-gonococcal } \\
\text { infection }\end{array}$} & \multirow{2}{*}{ Re-infection } & \multirow{2}{*}{ Failure } & & \multicolumn{2}{|c|}{ Within $1 w k$} & \multicolumn{2}{|c|}{ Within 2 wks } \\
\hline & & & & & & & No. & Per cent. & No & Per cent. \\
\hline $\begin{array}{l}1963 \star \\
1966 t \\
1968-9 \ddagger\end{array}$ & $\begin{array}{l}279 \\
238 \\
307\end{array}$ & $\begin{array}{l}207 \\
200 \\
253\end{array}$ & $\begin{array}{l}28 \\
36 \\
58\end{array}$ & $\begin{array}{l}24 \\
26 \\
19\end{array}$ & $\begin{array}{l}23 \\
17 \\
36\end{array}$ & $\begin{array}{r}11 \cdot 1 \\
8 \cdot 5 \\
14 \cdot 2\end{array}$ & $\begin{array}{l}12 \\
10 \\
27\end{array}$ & $\begin{array}{r}5 \cdot 8 \\
5 \cdot 0 \\
10 \cdot 7\end{array}$ & $\begin{array}{l}22 \\
19 \\
34\end{array}$ & $\begin{array}{r}10 \cdot 6 \\
9.5 \\
13.3\end{array}$ \\
\hline Total & 824 & 660 & $\begin{array}{l}122 \\
(18.5 \text { per cent.) }\end{array}$ & 69 & 76 & $11 \cdot 5$ & 49 & $7 \cdot 4$ & 75 & $11 \cdot 4$ \\
\hline
\end{tabular}


example Curtis and Wilkinson (1958) on the basis of penicillin sensitivity studies, have considered it reasonable to classify all recurrences within one week of therapy as failures and all those observed after one week as re-infections, irrespective of history of renewed exposure to risk. Other workers have taken 2 weeks as the critical period (which certainly agrees more closely with the findings based on history), and calculations on the basis of all three methods have been made in the Table.

By all three methods the results show a pattern varying with the years, the worst results being in the most recent series.

In the three series taken together, involving 824 patients, the failure rates based on a history of further sexual exposure varied between 8.5 and 14.2 per cent. If all recurrences in the first week were regarded as failures, the rates ranged from $5 \cdot 0$ to $10 \cdot 7$ per cent. If recurrences within 2 weeks were considered to be failures, the range of 10.6 to 13.3 per cent. closely resembled that found when the results were calculated on the basis of further sexual exposure.

Experience with the higher dose of 2.4 mega units aqueous procaine penicillin in a single injection The results observed with single doses of $2.4 \mathrm{mega}$ units of aqueous procaine penicillin in 1967 are shown in Table II and these are contrasted with the combined results obtained in the two most recent series using 1.2 mega units procaine penicillin.

With this increased dosage the failure rate as based on history was reduced from 11.7 to 5.8 per cent. Considering all recurrences within one week as failures, the rate fell from 8.2 to 3.3 per cent., and when 2 weeks was taken as the test period from 11.7 to 7.5 per cent.
Results obtained with 1.2 mega units procaine penicillin plus probenecid

Use of the kidney-blocking agent probenecid (Meads, Knight, and Izlar, 1951) enhances the peak serum levels and duration of injectable and orally-administered penicillins, and excellent cure rates have been obtained in areas of high prevalence of resistant strains of gonococci (Jensen, Kvorning, and Nørredam, 1963; Schmidt and Roholt, 1965) by the use of injections of 5 mega units crystalline penicillin $\mathrm{G}$ plus one dose of $1 \mathrm{~g}$. probenecid given 30 minutes before injection (Lomholt and Berg, 1966); the same dose of this penicillin preparation without probenecid would have produced unacceptable results.

Holmes and others (1967), in the Far East, were able to reduce the failure rate with single injections of 2.4 mega units procaine penicillin from nearly 30 per cent. to only 2 per cent. if multiple doses of probenecid were also given.

Preliminary observations on the effect of $1 \mathrm{~g}$. probenecid given simultaneously with 1.2 mega units procaine penicillin compared with results using the same dose of procaine penicillin without probenecid in alternate cases are shown in Table III.

The results are encouraging by all three methods of assessment, and the use of probenecid in this simple way holds hope of maintaining the effectiveness of single doses of penicillin of manageable size longer than might otherwise have been possible.

\section{Streptomycin}

An increasing proportion of strains of gonococci showing a lessened sensitivity to penicillin are completely resistant to streptomycin; not only is this antibiotic now useless in patients failing to respond

TABLE II Results with single injections of 2.4 mega units of procaine penicillin

\begin{tabular}{|c|c|c|c|c|c|c|c|c|c|c|c|}
\hline \multirow{3}{*}{ Year } & \multirow{3}{*}{$\begin{array}{l}\text { Dose } \\
\text { (mega units) }\end{array}$} & \multirow{3}{*}{$\begin{array}{l}\text { No. } \\
\text { treated }\end{array}$} & \multirow{3}{*}{$\begin{array}{l}\text { No. } \\
\text { followed }\end{array}$} & \multicolumn{3}{|l|}{ Result } & \multirow{3}{*}{$\begin{array}{l}\text { Percentage } \\
\text { failure of cases } \\
\text { followed }\end{array}$} & \multicolumn{4}{|c|}{ All recurrences } \\
\hline & & & & \multirow{2}{*}{$\begin{array}{l}\text { Non- } \\
\text { gonococcal } \\
\text { infection }\end{array}$} & \multirow{2}{*}{$R e$-infection } & \multirow{2}{*}{ Failure } & & \multicolumn{2}{|c|}{ Within 1 wk } & \multicolumn{2}{|c|}{ Within 2 wks } \\
\hline & & & & & & & & No. & Per cent. & No & Per cent. \\
\hline $\begin{array}{l}1967 \\
1966 \text { and } \\
1968-9\end{array}$ & $\begin{array}{l}2 \cdot 4^{\star} \\
1 \cdot 2\end{array}$ & $\begin{array}{l}280 \\
545\end{array}$ & $\begin{array}{l}240 \\
453\end{array}$ & $\begin{array}{l}54 \\
94\end{array}$ & $\begin{array}{l}35 \\
45\end{array}$ & $\begin{array}{l}14 \\
53\end{array}$ & $\begin{array}{r}5 \cdot 8 \\
11 \cdot 7\end{array}$ & $\begin{array}{r}8 \\
37\end{array}$ & $\begin{array}{l}3 \cdot 3 \\
8 \cdot 2\end{array}$ & $\begin{array}{l}18 \\
53\end{array}$ & $\begin{array}{r}7 \cdot 5 \\
11 \cdot 7\end{array}$ \\
\hline
\end{tabular}

* Morrison, Cobbold, Bor, Spitzer, Foster, and Willcox (1968).

TABLE III Results with 1.2 mega units of procaine penicillin plus $1 \mathrm{~g}$. probenecid

\begin{tabular}{|c|c|c|c|c|c|c|c|c|c|c|}
\hline \multirow{3}{*}{ Probenecid } & \multirow{3}{*}{ No. treated } & \multirow{3}{*}{ No. followed } & \multicolumn{3}{|l|}{ Result } & \multirow{3}{*}{$\begin{array}{l}\text { Percentage } \\
\text { failure of those } \\
\text { followed }\end{array}$} & \multirow{2}{*}{\multicolumn{2}{|c|}{$\frac{\text { All recurrences }}{A t 1 w k}$}} & & \\
\hline & & & Non- & & & & & & \multicolumn{2}{|c|}{ At $2 w k s$} \\
\hline & & & $\begin{array}{l}\text { gonococcal } \\
\text { infection }\end{array}$ & Re-infection & Failure & & No. & Per cent. & No. & Per cent. \\
\hline $\begin{array}{l}\text { Used } \\
\text { Not used }\end{array}$ & $\begin{array}{l}307 \\
307\end{array}$ & $\begin{array}{l}256 \\
253\end{array}$ & $\begin{array}{l}53 \\
58\end{array}$ & $\begin{array}{l}21 \\
19\end{array}$ & $\begin{array}{l}17 \\
36\end{array}$ & $\begin{array}{r}6.6 \\
14.2\end{array}$ & $\begin{array}{l}11 \\
27\end{array}$ & $\begin{array}{r}4 \cdot 3 \\
10 \cdot 7\end{array}$ & $\begin{array}{l}18 \\
34\end{array}$ & $\begin{array}{r}7 \cdot 0 \\
13 \cdot 3\end{array}$ \\
\hline
\end{tabular}


to penicillin, but failure rates in London are so high that it is unacceptable even as the first treatment in pencillin-allergic subjects (Table IV). It has been calculated (Spitzer and Willcox, 1968) that, if the number of resistant gonococci continues to increase at the present rate of acceleration, streptomycin will fail in no less than 85.8 per cent. of cases by 1971 .

\section{Other antibiotics}

Many other antibiotics can be used against gonorrhoea. Those given by injection include cephaloridine, kanamycin, spectinomycin, some tetracycline preparations, and chloromycetin. Those administered by mouth include semi-synthetic penicillins, such as phenoxymethyl penicillin, phenethicillin, and ampicillin; the many tetracyclines (tetracycline oxytetracycline, chlortetracycline, demethylchlortetracycline, methacycline, clomocycline, doxycycline); chloramphenicol, thiamphenicol, erythromycin, oleandomycin, spiramycin, rifampicin, and cephalexin (Willcox, 1968). Also the sulphonamides have again entered the list in combination with trimethoprim (Csonka and Knight, 1967). The use of antibiotic combinations has so far been investigated on only a limited scale (Willcox, 1968).
Some of these agents (e.g. chloramphenicol) have toxic risks which preclude their routine use in such a common condition as gonorrhoea, while others (including cephaloridine, the tetracyclines, and spiramycin) are likely to be less effective in cases failing to penicillin because of a measure of crossresistance (Reyn and Bentzon, 1968).

Moreover, the use of single dose methods with orally administered antibiotics has not usually given results commensurate with those obtained with penicillin by single injections, and it has been my experience, particularly with ampicillin (Willcox, 1964) and demethylchlortetracycline (Willcox, 1967), that better results are obtained when two oral doses are given 4 to 6 hours apart. Some recent experiences with other antibiotics are set out in Table V, which shows that a combination of rolitetracycline by injection plus tetracycline by mouth does not give such good results as those obtained with single injections of aqueous procaine penicillin; comparable results can be obtained with single oral doses of a new antibiotic rifampicin (Rimactane); and markedly superior results are obtained with demethylchlortetracycline given in two oral doses at an interval of 4 to 6 hours.

TABLE IV Results with $1 \mathrm{~g}$. streptomycin

\begin{tabular}{|c|c|c|c|c|c|c|c|}
\hline \multirow{2}{*}{ Year } & \multirow{2}{*}{ No. treated } & \multirow{2}{*}{ No. followed } & \multirow{2}{*}{ Suspected failure } & \multirow{2}{*}{$\begin{array}{l}\text { Percentage } \\
\text { failure of those } \\
\text { followed }\end{array}$} & \multicolumn{2}{|c|}{ Increase on previous } & \multirow{2}{*}{$\begin{array}{l}\text { Multiple of increase on } \\
\text { previous per cent. increases }\end{array}$} \\
\hline & & & & & No. & Per cent. & \\
\hline $\begin{array}{l}1951 \\
1956 \\
1961 \\
1966\end{array}$ & $\begin{array}{r}42 \\
55 \\
224 \\
130\end{array}$ & $\begin{array}{r}35 \\
46 \\
181 \\
104\end{array}$ & $\begin{array}{r}3 \\
5 \\
27 \\
33\end{array}$ & $\begin{array}{r}8 \cdot 5 \\
10 \cdot 2 \\
14 \cdot 9 \\
31 \cdot 7\end{array}$ & $\begin{array}{r}\overline{1 \cdot 7} \\
4 \cdot 7 \\
16 \cdot 8\end{array}$ & $\begin{array}{r}-\overline{20.0} \\
46 \cdot 1 \\
112.8\end{array}$ & $\begin{array}{l}- \\
2 \cdot 3 \\
2 \cdot 4\end{array}$ \\
\hline 1971 & - & - & - & $? 85 \cdot 8$ & $? 54 \cdot 1$ & $? 270 \cdot 7$ & $? 2 \cdot 4$ \\
\hline
\end{tabular}

TABLE V Recent experience with other antibiotics

\begin{tabular}{|c|c|c|c|c|c|c|c|c|c|c|c|}
\hline \multirow{3}{*}{ Antibiotic } & \multirow{3}{*}{ Dosage } & \multirow{3}{*}{$\begin{array}{l}\text { No. } \\
\text { treated }\end{array}$} & \multirow{3}{*}{$\begin{array}{l}\text { No. } \\
\text { followed }\end{array}$} & \multicolumn{3}{|l|}{ Result } & \multirow{3}{*}{$\begin{array}{l}\text { Percentage } \\
\text { failure } \\
\text { of those } \\
\text { followed }\end{array}$} & \multicolumn{4}{|c|}{ All recurrences } \\
\hline & & & & \multirow{2}{*}{$\begin{array}{l}\text { Non- } \\
\text { gonococcal } \\
\text { infection }\end{array}$} & \multirow{2}{*}{ Re-infection } & \multirow{2}{*}{ Failure } & & \multicolumn{2}{|c|}{ Within $1 w k$} & \multicolumn{2}{|c|}{ Within 2 wks } \\
\hline & & & & & & & & $\overline{N o}$ & Per cent. & No & Per cent. \\
\hline $\begin{array}{l}\text { Demethyl- } \\
\text { chlortetracycline* }\end{array}$ & $\begin{array}{l}\text { Two of } \\
1 \cdot 2 \text { g. each }\end{array}$ & 107 & 93 & 11 & 5 & 4 & $4 \cdot 3$ & 3 & $3 \cdot 2$ & 4 & $4 \cdot 3$ \\
\hline Rifampicint & $\begin{array}{l}900 \mathrm{mg} . \\
\text { single }\end{array}$ & 103 & 89 & 15 & 10 & 10 & $11 \cdot 2$ & 6 & $6 \cdot 7$ & 10 & $11 \cdot 2$ \\
\hline $\begin{array}{l}\text { Rolitetracyclinef } \\
\text { by injection } \\
\text { + tetracycline } \\
\text { phosphate by } \\
\text { mouth }\end{array}$ & $\begin{array}{l}350 \mathrm{mg} . \\
\quad+500 \mathrm{mg} .\end{array}$ & 48 & 45 & 9 & 4 & 7 & $15 \cdot 6$ & 6 & $13 \cdot 3$ & 8 & $17 \cdot 8$ \\
\hline $\begin{array}{l}\text { Procaine } \\
\text { penicillin }\end{array}$ & $\begin{array}{l}1 \cdot 2 \\
\text { mega units }\end{array}$ & 545 & 453 & 94 & 45 & 53 & $11 \cdot 7$ & 37 & $8 \cdot 2$ & 53 & $11 \cdot 7$ \\
\hline
\end{tabular}

* Willcox (1969). † Cobbold, Morrison, and Willcox (1968). $\quad$ † Unpublished data. 


\section{Summary and conclusions}

(1) Rising failure rates with single injections of penicillin in gonorrhoea are causing concern, particularly in the Far East, where the limit of what can be physically given by a single injection of procaine penicillin is being reached. In other areas rising resistance of the gonococcus to penicillin, although disquieting, is less serious, and in London it is still possible to achieve cure rates of 85.8 to 91.5 per cent. in male patients, using single injections of 1.2 mega units aqueous procaine penicillin.

(2) In patients treated with 2.4 mega units procaine penicillin in a single injection, the failure rate was reduced to 5.8 per cent. and a comparable reduction (6.6 per cent.) was also achieved if $1.0 \mathrm{~g}$. probenecid was administered orally simultaneously with an injection of 1.2 mega units procaine penicillin.

(3) Streptomycin is no longer effective enough in the treatment of gonorrhoea; a failure rate of 31.7 per cent. has occurred in London in male patients given $1.0 \mathrm{~g}$. of this drug. It is considered that if the present acceleration in resistance continues, streptomycin may fail in 85.8 per cent. of cases by 1971 .

(4) The numerous other antibiotics active against the gonococcus are listed, but the warning is given that gonococcal strains less sensitive to penicillin may become insensitive to other antibiotics also. Some recent experience with demethylchlortetracycline in two oral doses, rifampicin in a single oral dose, and rolitetracycline by injection plus tetracycline phosphate by mouth given at a single session are presented. Single doses of rifampicin gave comparable results to those obtained with single injections of 1.2 mega units procaine penicillin, but superior results (95.7 per cent. success) were obtained with two oral doses of demethylchlortetracycline.

\section{References}

Cobbold, R. J. C., MORRISON, G. D., and WILlcox, R. R. (1968). Brit. med. F., 4, 681.

-, SPITZER, R. J., Morrison, G. D., and Willcox, R. R. (1970). Postgrad. med. F., 46, in press.

CsonkA, G. W., and KNIGHT, G. J. (1967) Brit. f. vener. Dis., 43, 161.

CuRTIS, F. R., and WILKINSON, A. E. (1958). Ibid., 34, 70.

Jensen, P. E., Kvorning, S. A., and NøRREDAM, K. (1963). Ibid., 39, 238.

Holmes, K. K., Johnson, D. W., Floyd, T. M., and Kvale, P. A. (1967). F. Amer. med. Ass., 202, 467.

LETCHNER, E. H., and NICOL, C. S. (1961). Brit. F. vener. Dis., 37, 158.

LOMHOLT, G., and BERG, O. (1966). Ibid., 42, 1.

Meads, M., KNIGHT, V. H., and IzLaR, H. L. (1951). Sth. med. F. (Bgham, Ala.), 44, 297.

Morrison, G. D., Cobbold, R. J. C., BoR, S., SPITZER, R. J., FosteR, D. N., and WILLCox, R. R. (1968). Brit. f. vener. Dis., 44, 319.
Morton, R. S. (1963). Ibid., 39, 105.

ÖDEGAARD, K., and GJESSING, H. C. (1967). Ibid., 43, 284.

REYN, A., and Bentzon, M. W. (1968). Ibid., 44, 140.

Schmidt, H., and Roholt, K. (1965). Ugeskr. Laeg., $127,478$.

SPITZER, R. J., and Willcox, R. R. (1968). Acta derm.venereol. (Stockh.), 48, 537.

WILlcox, R. R. (1963). Brit. f. vener. Dis., 39, 164.

- (1964). Postgrad. med. F. Suppl., 40, 202.

- (1967). Brit. F. vener. Dis., 43, 157.

- (1968) In 'Current Problems in Dermatology' vol 2, 'Antibiotic Treatment of Venereal Diseases', ed. A. Luger, p. 101. Karger, Basel.

- (1969). Acta derm.-venereol. (Stockh.), 49, 103.

WHO (1969). Report of Second VD Seminar Western Pacific Region, Manila.

\section{Recents progrès dans le traitement de la gonococcie}

\section{SOMMAIRE ET CONCLUSIONS}

(1) L'augmentation du pourcentage d'échecs du traitement de la gonococcie après des injections uniques de pénicilline est inquiétante, en particulir en ExtrêmeOrient où l'on a atteint la limite de ce qui peut être, physiquement, administré de pénicilline procaïne en une seule injection.

Dans d'autres régions, la résistance du gonocoque à la pénicilline, quoique préoccupante, est moins sérieuse et, à Londres, il est toujours possible d'obtenir un taux de guérison de 85,8 à 91,5 pour cent, chez l'homme avec une injection unique de 1,2 méga-unités de pénicilline-procaïne en suspension aqueuse.

(2) Chez les malades traités par 2,4 méga-unités de pénicilline-procaïne en une injection, le taux des échecs fut ramené à 5,8 pour cent, et il en fut de même $(6,6$ pour cent) si lg. de probénécide était donné par voie buccale en même temps qu'une injection de 1,2 méga-unités de pénicilline-procaïne.

(3) Actuellement, la streptomycine n'est plus assez active dans le traitement de la gonococcie; avec lg., le taux d'échec a été de 31,7 pour cent à Londres chez les hommes. Si l'accroissement de la résistance continue au même rythme, on peut penser que la streptomycine échouera dans 85,8 pour cent des cas vers 1971 .

(4) On énumère les nombreux autres antibiotiques actifs contre le gonocoque, mais il faut être attentif au fait que les souches de gonocoques moins sensibles à la pénicilline peuvent devenir également insensibles aux autres antibiotiques. On rapporte quelques expériences récentes avec la déméthylchlortetracycline donneé per os en deux fois, avec la rifampicine donnée en une seule dose buccale, et avec la rolitétracycline administrée par injection en association avec le phosphate de tétracycline donné par la bouche au cours de le même séance. Des doses uniques de rifampicine ont donné des résultats comparables à ceux qui avaient été obtenus avec des injesctions uniques de 1,2 méga-unités de pénicillineprocaïne, mais des résultats supérieurs $(95,7$ pour cent de succès) ont été obtenus avec deux doses de déméthylchlortétracycline données par voie buccale. 